\title{
Does The Government Policy and T-Servqual Make Tourist Satisfaction?
}

\author{
Jumadi $^{1}$, Samsul Bakri ${ }^{2}$, Wuku Astuti ${ }^{3}$, Amelia Nanda Sukma ${ }^{4}$ \\ ${ }^{1}$ Departement Management University of Widya Mataram \\ 2,3,4 Departement Accounting University of Widya Mataram
}

\begin{abstract}
Government policy and tourism service quality (T-Servqual) are important aspects of the tourism industry and can be increased performance organization and Tourist Satisfaction (customer satisfaction). This research aims to investigate government policy and T-Servqual toward customer (tourist) satisfaction in the Indonesia Tourism Industry. The sample size was 420 respondents with propulsive sampling used to determine the sample. The main instrument in this study is a questionnaire. The analysis used to examine the hypothesis of the study is structural equation modeling using AMOS version 20.0 software. The result of the study shows that: T-Servqual and government policy influence customer satisfaction. Nevertheless, government policy has the most influence on customer satisfaction. Therefore the manager in the tourism industry should improve more the TServqual.
\end{abstract}

KEYWORDS: T-Servqual, government policy, tourist, satisfaction

\section{INTRODUCTION}

The interaction between employees the customer in the service industry is determined as a significant part of the market offering and the employee role in determining customer satisfaction is much greater. So the effectiveness of the service quality programs from the customer perception of service quality, quality, and customer satisfaction. One of the factors affecting customer satisfaction is the service quality it according to the results of research conducted by (Hui-fen and Lee-Hui, 2010); (Agyapong, 2011); (Suki, 2012); (Wang and Due Lee, 2012); (Hossain, 2012); (Osman and Sentosa, 2013) which the states of the service quality influence the customer satisfaction. The tourist satisfaction is influenced by image, risk, and services received climate (AL-Majali, 2012).

The quality standards changed from the traditional concept which based on compliance with the standards set by the manager to shift into quality is determined by the consumer, which has been implications for the marketing function (Jumadi, 2010). The service quality should be developed for measuring the quality of long-term care, subjective and complex. Nevertheless, customer satisfaction cannot be predicted with the evaluation of service quality. In addition to the service quality that government policy can achieve performance as a generator in the field of tourism (Kouthouris and Alexandris, 2005). The additional service quality, the government policy in favor of the tourism services can provide a level of assurance to the tourism activity.

Therefore this study aims to investigate the implications of the effectiveness of the government policies and service quality toward customer satisfaction. The Service quality assessment is used to determine the rating outlook for the service quality and government policies to render on the tourism industry in Indonesia. Based on the research background, the research problem in this study is: How to influence government policy and service quality to customer satisfaction?

\section{THEORETICAL FRAMEWORK AND LITERATURE REVIEW}

\section{Customer Satisfaction}

The success of an organization is influenced by the ability to identify customer needs and wants to provide satisfaction. Determining customer needs and wants to satisfy customers is not easy, this is because the needs and desires of customers are dynamic from time to time. In the service industry, customer satisfaction is always influenced by the quality of the interaction between customers and employees to obtain the services purchased. The sources of customer satisfaction and dissatisfaction, according to (Zeithmal, Bitner, Gremler, 2006) each lie in the delivery of interactive services, namely: recovery, responses to service delivery failures, adaptability, anticipation, and adaptation to customer needs for service, spontaneity, providing something impressive and unexpected as a form of compensation for failure, and coping, the ability to manage situations. 


\section{International Journal of Current Science Research and Review}

ISSN: 2581-8341

Volume 05 Issue 02 February 2022

DOI: 10.47191/ijesrr/V5-i2-27, Impact Factor: 5.825

IJCSRR@ 2022

www.ijesrr.org

Customer satisfaction is a major challenge for managers, including in the tourism industry. Therefore marketing strategy focused on how to attract more tourists to visit (Meleddu et al., 2015). According to (Phillips et al, 2011) tourist satisfaction is "overall feeling satisfied with what tourists feel after visiting tourist attractions and fulfilling travel expectations and needs ". Research on satisfaction helps provide information on how well the destination can meet the needs of tourists (Mao and Zhang, 2014). Tourist satisfaction is a very important thing in tourism management, tourist satisfaction is identified as a function of performance and perceived expectations, the behavior of satisfied customers will not easily shift. people's judgments about goals, different attributes are important to define overall satisfaction and the intention of tourists to return Increase tourists' level of satisfaction and destination loyalty is very important and necessary in tourism destination management (Khuong and Ha, 2014).

\section{The Government Policy}

Projects carried out by the government encouraged to be able to the creation of many comparative advantages. Likewise with the tourism sector that the strength of tourism as a factor of economic growth varies depending on local conditions and geographic location, level of urbanization, availability of adequate facilities and this all depends on government policy. The government is the main actor in tourism development (Bramwell, 2011), the government is usually more interventionist in carrying out tourism development than in other sectors (Ruhanen, 2013). According to (Hall, 2005), the government has seven internal functions of tourism development which include: planning, coordination, making entrepreneurial legislation, stimulation, social tourism, and the protection role of the public interest.

According to (Chandler and Plano, 1988) which is supported by (Tangkilisan, 2003) Public policy is the strate gic utilization of the resources that exist to solve the problems of the public or the government. The government policy of Indonesia tourism as the develop and intensify the promotion of tourism, setting up and improving the quality waters and tourism products, develop tourism areas and new products, especially in the eastern region of Indonesia, improving the quality of human resources in the field of tourism and implement a sustainable national campaign (Karyono, 1997). So (Liu, 2012) explained that public policy is made through some kind of hybrid arrangement involving different actors, including some who represent the private or nongovernmental organizations, and implemented independently between public and private. Meanwhile (Asaomah, 2013) explained the policy is a process or series of patterns of government activities or decisions that are designed to fix some common problems, whether real or not formulated, implemented and evaluated by the actors in the political system, for example, judges, legislators, executor and administrators, public policy can be changed based on new information or better. So (Asomah, 2013) explains the development of the policy of tourism should consider the various stakeholders and agencies involved in tourism development.

The public believes that the performance of government institutions is one the strongest determinant of citizen trust. Citizens' trust in government produces the desired economic performance results and meets their expectations (Luhiste, 2006). A government that is unable to face economic challenges such as poverty or unemployment will cause public distrust. This is following the results of research (Mishler and Rose, 2001; 2005); (Wang, 2005); (Wong et al., 2011). According (Nunkoo et al, 2012) explain that citizens' perceptions of government are in the economic sector tourism has a positive effect on political trust. In developing the tourism industry, a political desire or policies oriented to the tourism industry are needed. Political will is a guarantee or a means of increasing confidence in the seriousness of the government in developing the tourism industry. To achieve this, one of the government policies in the tourism sector in Indonesia is how to provide good or quality services to tourists to increase tourist satisfaction.

\section{T-SERVQUAL}

According to (Grönroos, 1984) that service quality is the result of a consumer evaluation process that compares expectations with the services received. Meanwhile (Parasuraman et al., 1985) explained that service quality is the gap between customer expectations and the service received. Service quality is one of the most important factors for fulfilling the needs of both consumer goods and or services. Meanwhile, according to (Stonebraker and Leong, 1994) that service quality is a process to identify customer needs for the design of goods and services whether it is following the needs of the service system based on customer specifications. In addition, these experts(Vavra, 1995) explain that service quality is the appearance of the presentation of services and goods that adapt to customer needs. Meanwhile (Chih Yu et. Al, 2005) explained that quality is the consumer's 


\section{International Journal of Current Science Research and Review}

ISSN: 2581-8341

Volume 05 Issue 02 February 2022

DOI: 10.47191/ijesrr/V5-i2-27, Impact Factor: 5.825

IJCSRR@ 2022

www.ijcsrr.org

expectation as a prediction of what might happen in the future. According to (Zeithaml, Bitner \& Glammer, 2009) said that service quality is an assessment that is related to service excellence.

Service quality is a multidimensional concept because every industry has a different approach and measurement dimensions. Service quality is one of the factors that can affect the level of tourist satisfaction. Based on research (Suki, 2012) explains that assurance, responsiveness, and tangible have no effect on customer satisfaction, only empathy and reliability have an effect on customer satisfaction. Meanwhile (Albayrak, and Aksoy, 2010) stated that the tangible element has a more significant effect on customer satisfaction than the intangible element. Meanwhile (Agyapong, 2011) explains that the dimensions of service quality which include tangible, reliability, responsiveness, competency courtesy, feeling secure, communication, and customer understanding are good predictors of customer satisfaction. The results of the study (Canny and Hidayat, 2012) explain that in general service quality can affect customer satisfaction, but partially the results show that the dimensions of empathy do not affect customer satisfaction. This is also supported by (Hui-fen and Lee-Hui, 2010); (Wang and Lee, 2012); (Hossain, 2012); (Osman and Sentosa, 2013); (Jumadi, 2017) which states that service quality affects tourist satisfaction. In contrast to the opinion of (Kouthouris and Alexandris, 2005), customer satisfaction cannot be predicted by evaluating service quality. Quality has changed from a standard-based concept set by managers to quality determined by consumers, and this will have implications for the marketing function (Jumadi, 2010). Service quality must be developed so that it can be used to measure long-term service quality, subjective and complex.

Service quality in the tourism industry is a service performance against tourism attributes (Chen and Chen, 2010). Service quality is very important in the tourism industry is experiencing increasingly fierce competition. With the high quality of good service, tourist destinations are more likely to attract both first-time and repeat visitors. Travelers who have good experiences will tend to inform friends and family which will create repeat business and new business potential (Vassiliadis et al., 2008). According to (Tosun et al, 2015), "service quality is determined as a tourist rating of performance at a tourist destination ". According to (Leong et al, (2015), Tourist satisfaction is influenced by the quality of service. Khan et al. (2013) stated that destinations that provide quality service can be attractive to tourists and provide tourist satisfaction. Besides, several kinds of literature found service quality is the main factor of tourist satisfaction (Silvestri, Aquilani, \& Ruggieri, 2017); (Hallak, Assaker \& El-Haddad, 2018).

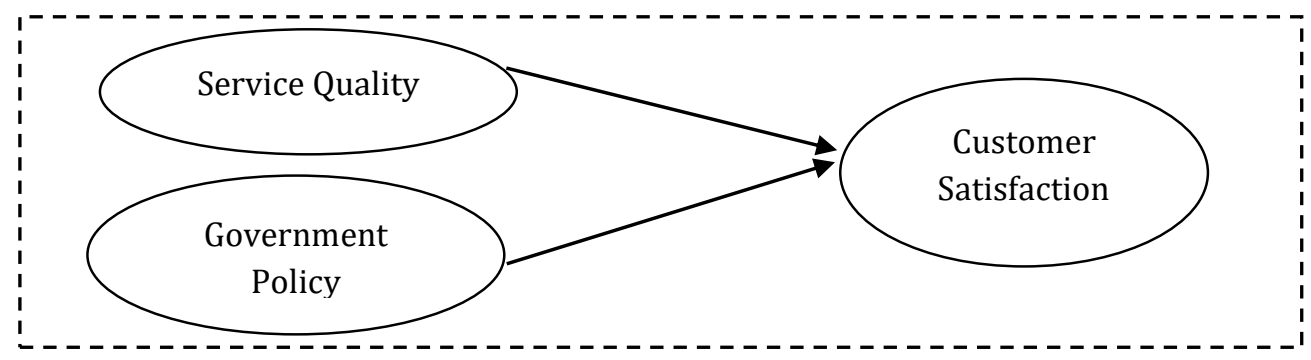

Figure 1. Research Paradigm

\section{METHODS}

This study examines the influence of service quality variables and government policies on customer satisfaction. The sample used in this study is based on propulsive sampling. The number of samples is set at least 5 to 10 times the number of parameters (Hair, 1998). Based on these provisions, the sample is set as many as 420 respondents. Data collection of perceptions of tourists visiting destinations in Indonesia through 1. Observation, with direct observation in the field. 2. Distribution of questionnaires for 5 scale questionnaire design.

\section{Model Specification}

The costumer satisfaction model used in the analysis is as follow:

$\eta 1=\gamma 1.1 \xi 1+\gamma 1.2 \xi 2+\zeta 1$

$\eta 1=$ costumer satisfaction

$\xi 1=$ Service Quality

$\xi 2=$ Government Policy 


\section{International Journal of Current Science Research and Review}

ISSN: 2581-8341

Volume 05 Issue 02 February 2022

DOI: 10.47191/ijesrr/V5-i2-27, Impact Factor: 5.825

IJCSRR@ 2022

www.ijcsrr.org

\section{Definition of Variable}

\section{Service Quality}

The measurement of the service quality in this study used the model of SERVQUAL, Parasuraman, \& Berry Ziethaml, 1988) and modified by the model of (Lovelock \& Wird, 2007) with dimensions of Security and access, so the dimensions of T-Servqual in this research is SETARRA (security, empathy, tangibles, assurance, responsiveness, reliability and access (Jumadi, 2017). Based on this, the researcher can be concluded that service quality is the process of identifying the customers' needs that accompanied the presentation of the services based on standards requirements to meet customer expectations through services provided to external customers. The Dimensions of Tourism Service Quality (T-Servqual) adopt (Jumadi, 2015):

1. Security, security is overall freed from a sense of the dangers/hazards, safety risks, and doubts.

2. Empathy, empathy has involved the provision of caring, individual attention to the customer. This empathy includes access, communication, and understanding of customers. Empathy is also concerned with concern, individual care that employees of the company provide to clients.

3. Tangible, tangible is the physical appearance of the facility, equipment, and employees' communication or promotional materials

4. Assurance, assurance is involved knowledge and modesty of employees and their ability to convey trust and confidence.

5. Responsiveness, responsiveness is willingness is happy to help customers and hosting services, especially in handling customer complaints.

6. Reliability, reliability can deliver services following the promised, accurately and reliably

7. Access is, access is easy to reach and easy to contact.

\section{Government Policy}

Public policy is the strategic utilization of the resources that exist to solve the problems of the public or the government. The government policy of Indonesia tourism as the development and intensifying the promotion of tourism, setting up and improving the quality waters and tourism products.

\section{Customer Satisfaction}

The customer satisfaction from the viewpoint of a tourist has been measured depending on several criteria which consists of six indicators that include:

1) General evaluation of the services

2) Evaluation of hotel services, restaurants, and places

3) Evaluation of customer value related to the price of services

4) Evaluate the level of accommodation services

5) Quality evaluation of transportation

6) Evaluation of the quality of information.

\section{TECHNIQUES, DATA ANALYSIS}

The data analysis of hypothesis testing is done by using an SEM with a data processor using AMOS version 20.0 software.

\section{Confirmatory Factor Analysis}

Based on the evaluation of SEM assumptions, further analysis is an analysis of the suitability of the model proposed in this study with the various criteria of goodness-of-fit. The results of the evaluation with the SEM model, as shown in Table 1 below.

Table.1. The test of Suitability Model

\begin{tabular}{llll}
\hline Suitability of the Model & Value Standart & Result & Meaning \\
\hline Chi Squares & Small Expected & 1021 & - \\
\hline P Value & $>0,05$ & 0,000 & - \\
\hline RMSEA & $<0,1$ & 0,061 & Good \\
\hline CMIN/DF & $2-5$ & 2.560 & Good \\
\hline
\end{tabular}




\section{International Journal of Current Science Research and Review}

ISSN: 2581-8341

Volume 05 Issue 02 February 2022

DOI: 10.47191/ijesrr/V5-i2-27, Impact Factor: 5.825

\begin{tabular}{llll}
\hline TLI & $\geq 0,9$ & 0,9 & Good \\
\hline CFI & $\geq 0,9$ & 0,9 & Good \\
\hline NFI & $\geq 0,9$ & 0,9 & Good \\
\hline
\end{tabular}

Source: Primary data processed

The Base on table 1 shows the results of the evaluation of the full model for SEM has been demonstrated of the criteria for each measure of goodness of fit value is a CFI, NFI, TLI has met the criteria, whereas, Cmin / DF and RMSEA are following the expected criteria. Based on this result can be concluded the overall structural model has been able to produce a level of truth estimation. Thus, the testing of the research hypotheses can be done.

\section{DISCUSSION}

The research to investigate influence The Tourism service quality and government policy toward customer satisfaction. Testing the hypothesis is needed to determine the effect of tourism service quality and government policy on customer satisfaction. Then, based on the results of the data analysis show that CR value is identical to the value of it on the results of the processing as compared with the critical value \pm 1.96 at the significant level of $0.05(5 \%)$ as shown formulation of Satisfaction model: $\mathbf{0 . 2 3 3} \xi \mathbf{1}$ $+0.333 \xi 2+\zeta$

\section{Government Policy and Satisfaction}

The hypothesis of the government policy influence toward customer satisfaction is proven that indicated by the value of statistic test with $(ß)=0,333 \mathrm{SE}=0.88$ and $\mathrm{CR}=4.038$ and $\mathrm{p}=0.000(* * *)$. This means empirically that government policy can increase customer satisfaction. The hypothesis of this study will examine the results of research conducted by (Jumadi, 2014) That government policy can create comfort to tourists because government policy can provide guarantees to the visiting tourists. This is in line with the results of (Jumadi, 2017) which states that government policies affect the satisfaction of consumer satisfaction in Indonesia. Based on the research to be increased to the customer satisfaction are developed the government policy of Indonesia tourism and intensify the promotion of tourism, setting up and improving the quality waiters and tourism products, develop tourism areas, develop new products, security legal protection, and information access.

\section{Tourism Service Quality and Satisfaction}

The new dimension of T-Servqual in the research is SETARRA (security, empathy, tangibles, assurance, responsiveness, reliability, and access). Based on this, the researcher can be concluded that service quality is the process of identifying the customers' needs that accompanied the presentation of the services based on standards requirements to meet customer expectations through services provided to external customers. The hypothesis of the influence of the service quality on customer satisfaction, the hypothesis of this study will examine the results of research conducted by (Albayrak, 2010); (Suki, 2012); (Canny and Hidayat, 2012). The statistical test showed there is significant research between service quality on customer satisfaction, this means the hypothesis is proven by the results of the statistical test indicated by the value of $(B)=0.233 \mathrm{SE}=0,035 \mathrm{dan} \mathrm{CR}=3.217$ and $\mathrm{p}=0.001$ signs at 0.01 . This means the stronger the service quality, the higher the level of customer satisfaction. This is following (Hui-fen and Lee-Hui, (2010); (Agyapong, 2011); (Suki, 2012); (Wang and Due Lee, 2012); (Hossain, 2012); (Osman and Sentosa, 2013) which states that service quality influences customer satisfaction. It is also supported by research (AL- Majali, 2012); (Jumadi (2017) who explain that satisfaction is influenced by service climate.

Based on the results of the research can be concluded that Tourism service quality influences customer satisfaction. The results of this study support the research conducted by (Albayrak, 2010); (Canny and Hidayat, 2012). This happens because the nature of the employee's job in the tourism industry caters to travelers in domestic tourist specialty more in touch with the direct interaction and repetitive and not long-lasting. The influence of the service quality on customer satisfaction indicates the behavior of employees in performing the service has become a measure of service quality. However, the results of this study do not support the results study by (Suki, 2012) which states that service quality can’t influence customer satisfaction.

\section{CONCLUSION}

Based on the result of the research above overall can be concluded that: Tourism service quality and government policies influence satisfaction. The government policy has a more dominant influence on customer satisfaction and the new finding in this 


\section{International Journal of Current Science Research and Review}

ISSN: 2581-8341

Volume 05 Issue 02 February 2022

DOI: 10.47191/ijesrr/V5-i2-27, Impact Factor: 5.825

IJCSRR@ 2022

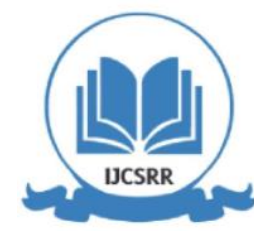

$\underline{\text { www.ijcsrr.org }}$

study. Tourism service quality and good government policies were undertaken by the effective manager sufficiently to realize satisfaction rating. The better course of the tourism service quality and good government policies able to assure the tourists visited.

Based on the above, it can be concluded overall that: the first, this study does not support the results of the study (Kouhtoris and Alaxandiras, 2005) which states that Servqual is not suitable for measuring the quality of tourism services, especially for outdoor tourism. The second, this study supports the research by (Suki, 2012); (Albayrak, 2010); (Canny and Hidayat, 2012) which states that service quality is an important factor in determining satisfaction. It also supports research by (Jusem et. Al, 2014) that states the concept of service quality that is suitable for measuring the service quality using dimensions of the tangible, empathy, responsiveness, reliability, and assurance. Based on (Jumadi 2017) the concept of service quality in this study expanded into the seven dimensions of the T-SERVQUAL that include security, empathy tangible, assurance, responsiveness, reliability, and access, so the new finding of the dimension of the tourism service quality is SETARRA. The best of the tourism service quality and government policy-oriented to tourism can increase tourist satisfaction. This means the government policy can encourage the mode of creating the tourists' satisfaction. The tourism service quality and government policies were undertaken by the manager sufficiently effectively to realize customer satisfaction ratings.

\section{SUGGESTION}

Based on the research findings the suggestion for tourism management is to design decisions based on the relationship of variables that have a strategic substance which can be a major foothold in providing make customer satisfaction can be done by: First The tourism managers should be an improvement of the tourism service quality with setup of security, empathy, tangibles, assurance, responsiveness, reliability, and access. The second, government, particularly the department of tourism should coordinate with the tourism industry to design and create a policy that is oriented and supports the development of the tourism industry.

\section{REFERENCES}

1. Agyapong G. K.Q, .(2011). The Effect of Service Quality on Customer Satisfaction in the Utility Industry - A Case of Vodafone (Ghana), International Journal of Business and Management Vol. 6, No. 5; May.

2. Albayrak, TC, M., and Aksoy, S. (2010). Relationships of the Tangible and Intangible Elements of Tourism Products with Overall Customer Satisfaction. International Journal of Trade, Economics, and Finance, Vol. 1, No. 2, pp. $140-143$.

3. AL-Majali Malek Mohammad. (2012). International Tourists Satisfaction: Case of Jordan. International Business Research; Vol. 5, No. 9; 2012. ISSN 1913-9004 E-ISSN 1913-9012 Published by Canadian Center of Science and Education

4. Asamoah Kwame. (2013). Policy implementation: A Tool for Enhancing Tourism Development in Ghana. Journal of Law, Policy and Globalization www.iiste.org ISSN 2224-3259 (Online)Vol.10, pg 19-29

5. Assael, H. (2008). Consumer Behavior and Marketing Action, (6 th Eds.). New Delhi: Cengage Learning.

6. Bramwell, B. 2011 Governance, the state and sustainable tourism: a political economy approach, Journal of Sustainable Tourism, vol. 19(4/5), pp. 459-477

7. Cany Ivyanno, Hidayat Nila. (2012). The Influence of Service Quality and Tourist Satisfaction on Future Behavioral Intentions: The Case Study of Borobudur Temple as a UNESCO World Culture Heritage Destination. DOI: 10.7763/IPEDR. V50. 19

8. Chen, C. F., \& Chen, F. S. (2010). Experience quality, perceived value, satisfaction, and behavioral intentions for heritage tourists. Tourism Management, 31(1), 29-35.

9. Chih Yu Alvin Hung, Morais Duarte, Chick Garry,. (2005). Service Quality in Tourism: a Case Study of the 2001 Study Tour of Taiwan, Proceedings of the Northeastern Recreation Research Symposium

10. Grönroos C. (1984). "A Service Quality Model and its Marketing Implications", European Journal of Marketing, Vol. 18 Iss: 4 , pp. $36-44$

11. Hallak, R., Assaker, G., \& El-Haddad, R. (2018). Re-examining the relationships among perceived quality, value, satisfaction, and destination loyalty: A higher-order structural model. Journal of Vacation Marketing, 24(2), 118-135. 


\section{International Journal of Current Science Research and Review}

ISSN: 2581-8341

Volume 05 Issue 02 February 2022

DOI: 10.47191/ijesrr/V5-i2-27, Impact Factor: 5.825

IJCSRR@ 2022

www.ijesrr.org

12. Hall, C. M. (2005). The role of government in the management of tourism: the public sector and tourism policies, In: L. Pender, R. Sharpley (Eds.) The management of tourism (pp. 217-230), Thousand Oaks, CA: Sage Publications

13. Hair. J.F. Jr., Anderson, R. E., Tatham, R. L., Black, W. C. (1998). Multivariate Data Analysis With Readings. PrenticeHall, Inc.

14. Hirankitti, P., Mechinda, P., \& Manjing, S. (2009). Marketing Strategies of Thai Spa Operators in Bangkok Metropolitan. The International Conference on Applied Business Research ICABR Valletta (St.Julians)-Malta.

15. Hossain Sarker, Mohammad Amzad, Wang Aimin, Sumayya Begum. (2012). Investigating the Impact of Marketing Mix Elements on Tourists 'Satisfaction: An Empirical Study on East Lake, European Journal of Business and Management Vol 4, No.7, 2012 P273-282

16. Hui-fen Tsou, Lee-Hui Lin. (2010). Customer Satisfaction on Dining Area/Hotel Circumstance and Service Quality in the Tourist Industry: A Case Study of Visitors to Green Island. The Journal of International Management Studies, Volume 5, Number.

17. Jumadi. (2010). Pengaruh Kualitas Layanan Ruang Publik Kota Yogyakarta terhadap Kepuasan Pengunjung (studi kasus pada Taman Pintar Yogyakarta). Prosiding Seminar Nasional Manajemen FE UII Yogyakarta pg; 1-25

18. Jumadi. (2014). Pengembangan Model Pemasaran Pariwisata Terpadu Dalam Mewujudkan Keberlanjutan Pariwisata di Daerah Istimewa Yogyakarta. Laporan Penelitian PDD. Universitas Widya Mataram Yogyakarta: Yogyakarta.

19. Jumadi. (2015). Pemasaran Kepariwisataan Terpadu, Bimotry: Yogyakarta

20. Jumadi, Dwi Kartini, Indiastuti, R. \& Hasan, M. (2017). External Marketing, Government Policy and T-Serqual toward Customer Satisfaction in Indonesia Tourism Industry. International Journal of Management, Accounting, and Economics. Vol. 4, No. 1, ISSN 2383-2126 (Online) pg 43-55.

21. Karyono A. Hari. (1997). Kepariwisataan. Jakarta: PT. Grasindo

22. Khan, A.H., Haque, A.K.M. \& Rahman, S. (2013). What makes tourists satisfied? An empirical study on Malaysian Islamic tourist destinations. Middle East Journal of Scientific Research, Vol. 14, No. 12, pp. 1631-1637.

23. Khuong, M.N. \& Ha, H.T.T. (2014). The influences of push and pull factors on the international leisure tourists' return intention to Ho Chi Minh City, Vietnam: a mediation analysis of destination satisfaction. International Journal of Trade, Economics, and Finance, 5, 490-496.

24. Kouthouris Charilaos. (2005). Can Service Quality Predict Customer Satisfaction and Behavioral Intentions In The Sport Tourism Industry? An Application of The SERVQUAL Model In An Outdoors Setting. Journal of Sport Tourism 10(2), $101-111$

25. Leong, L. Y., Hew, T. S., Lee, V. H., \& Ooi, K. B. (2015). An SEM-artificial-neural-network analysis of the relationships between SERVPERF, customer satisfaction, and loyalty among low-cost and full-service airlines. Expert Systems with Applications, 42(19), 6620-6634

26. Liu I.-C. (2012). The Research of Medical Tourism Policy Network in Taiwan. Sociology Mind. Vol.2, No.4, pg:457-463

27. Lovelock, Christoper, H Witz, Jochen. (2007). Service Marketing People Technology. Pearson Prentice Hall Fith Edition, USA.

28. Luhiste, K. (2006): Explaining trust in political institutions: some illustrations from the Baltic States, Communist and Post-communist Studies, vol. 39, pp. 475-496.

29. Mao, I. Y. \& Zhang, H. Q. (2014). Structural relationships among destination preference, satisfaction, and loyalty in Chinese tourists to Australia. International Journal of Tourism Research, 16(2), 201-208.

30. Meleddu, M., Paci, R., \& Pulina, M. (2015). Repeated behavior and destination loyalty. Tourism Management, 50, 159171

31. Mishler, W., Rose, R. (2001). What the origins of political trust? Testing institutional and cultural theories in postcommunist societies, Comparative Political Studies, no. 34, pp. 30-62.

32. Mishler, W., Rose, R. (2005). What are the political consequences of trust? A test of cultural and institutional theories in Russia, Comparative Political Studies, vol. 38(9), pp. 1050-1078.

33. Nunkoo, R., Gursoy, D. (2012). Residents' support for tourism: an Identity perspective, Annals of Tourism Research, vol. 39(1), pp. 243-268. 


\section{International Journal of Current Science Research and Review}

ISSN: 2581-8341

Volume 05 Issue 02 February 2022

DOI: 10.47191/ijesrr/V5-i2-27, Impact Factor: 5.825

IJCSRR@ 2022

34. Osman Zahir, Ilham Sentosa. (2013). Mediating Effect of Customer Satisfaction on Service Quality and Customer Loyalty Relationship in Malaysian Rural Tourism. International Journal of Economics Business and Management Studies. IJEBMS pg: 25-37

35. Parasuraman et al.. (1985). A Conceptual Model of Service Quality and Its Implication for Future Research. Journal of Marketing. Pg. 41-50

36. Phillips, W. J., Wolfe, K., Hodur, N., \& Leistritz, F. L. (2013). Tourist word of mouth and revisit intentions to rural tourism destinations: A case of North Dakota, USA. International Journal of Tourism Research, 15(1), 93-104

37. Ruhanen, L. (2013): Local government: facilitator or inhibitor of sustainable tourism development, Journal of Sustainable Tourism, vol. 21(1), pp. 80-98

38. Silvestri, C., Aquilani, B., \& Ruggieri, A. (2017). Service quality and customer satisfaction in thermal tourism. The TQM Journal, 29(1), 55-81

39. Stonebraker, P. W., \& Leong, K. G. (1994). Operating strategy: Focusing on competitive excellence. Allyn and Bacon, Massachusetts, USA.

40. Suki Norazah Mohd. (2012). Examining Hotel Service Quality Elements Effects on Overall Tourists Satisfaction, European Journal of Social Sciences, ISSN 1450-2267 Vol.30 No.4 pp. 646-653

41. Tangkilisan, Hessel Nogi S. (2003). “Teori dan Konsep Kebijakan Publik” Dalam Kebijakan Publik yang Membumi, Konsep, Strategi Dan Kasus, Yogyakarta: Lukman Offset dan YPAPI.

42. Thamrin. (2012). The Role of Service Marketing Mix and Ship Service Quality towards Perceived Value and Its Impact to Ship Passenger's Satisfaction In Indonesia, Global Journal of Management and Business Research. Volume 12 Issue 3 Version 1.0

43. Tosun, C., Dedeoğlu, B. B., \& Fyall, A. (2015). Destination service quality, affective image and revisit intention: The moderating role of past experience. Journal of Destination Marketing \& Management, 4(4), 222-234.

44. Wang Ming-Chieh et.al. (2012). The Mediating Effect of Quality of Service on the Effectiveness of Employee Training and Customer Satisfaction. International Research Journal of Finance and Economics. ISSN 1450-2887 Issue 90

45. Wang, Z. (2005): Before the emergence of critical citizens: economic development and political trust in China, International Review of Sociology, vol. 15(1), pp. 155-171

46. Wong, T. K., Wan, P., Hsiao, H. M. (2011): The bases of political trust in six Asian societies: institutional and cultural explanations compared, International Political Science Review, vol. 32(3), pp. 263-281

47. Vavra, T. G. (1995). After Marketing How to Keep Customer for Life Through Relationship Marketing, New York. McGraw-Hill

48. Vassiliadis, C., Bista, R., \& Fotiadis, A. (2008). Basic service quality dimensions in tourist destination planning. Journal of Tourism Challenges and Trends, 1(2), 33-44

49. Zeithaml Valerie A, Bitner Mary Jo, Gramler Dwayne D. 2009.” Service Marketing Integrating Customer Focus Across the Firm", Mc Graw-Hill.

Cite this Article: Jumadi, Samsul Bakri, Wuku Astuti, Amelia Nanda Sukma (2022). Does The Government Policy and TServqual Make Tourist Satisfaction?. International Journal of Current Science Research and Review, 5(2), 532-539 